\title{
Studies in sheep on the absorption of magnesium from a low molecular weight fraction of the reticulo-rumen contents
}

\author{
BY N. D. GRACE*, I. W. CAPLE†t AND A. D. CARE \\ Department of Animal Physiology and Nutrition, University of Leeds, Leeds LS2 9JT
}

(Received 13 April 1987- Accepted 28 August 1987)

1. Six sheep, three animals per diet, were prepared with rumen fistulas and fed on frozen grass or grass-maize pellets to give magnesium intakes of 1.79 and $2.23 \mathrm{~g} / \mathrm{d}$ respectively. The mean apparent availabilities of $\mathrm{Mg}$ in sheep fed on frozen grass and grass-maize pellets were 0.31 and 0.36 respectively.

2. The rumen contents were fractionated by straining the digesta through linen cloth and then differentially centrifuged to give $20000 \mathrm{~g}$ and $100000 \mathrm{~g}$ supernatant fractions.

3. In all sheep, regardless of diet, at 4 and $16 \mathrm{~h}$ after a meal, 50 and $60 \%$ respectively of the total $\mathrm{Mg}$ in the rumen contents was found in strained rumen fluid while 30 and $38 \%$ respectively of the total $\mathrm{Mg}$ was found in the $100000 \mathrm{~g}$ supernatant fraction.

4. The net absorption of $\mathrm{Mg}$ from the temporarily isolated and washed reticulo-rumen was studied using either $100000 \mathrm{~g}$ supernatant fractions of rumen contents from sheep fed on one or other of the two diets, or inorganic buffers containing the same concentration of $\mathrm{Mg}$ and other macroelements.

5. The $\mathrm{Mg}$ was readily absorbed from the $100000 \mathrm{~g}$ supernatant fraction placed in the rumen with the rate of absorption being $7.3 \mu \mathrm{mol} / 1$ per $\min (505 \mathrm{mg} / \mathrm{d})$ from the supernatant fraction obtained from sheep fed on frozen grass and $11.3 \mu \mathrm{mol} / 1$ per $\min (781 \mathrm{mg} / \mathrm{d})$ from the supernatant fraction from sheep fed on grass-maize pellets. In the same sheep, the previously described rates of $\mathrm{Mg}$ absorption from the $100000 \mathrm{~g}$ supernatant fraction were similar to those obtained from the comparable inorganic buffers.

6. The effects of varying concentrations of potassium and sodium on the net absorption rate of $\mathrm{Mg}\left(\mathrm{as}^{24} \mathrm{Mg}\right)$ and on the one-way effux of $\mathrm{Mg}\left({ }^{2}{ }^{28} \mathrm{Mg}\right.$ ) from supernatant fractions or rumen fluid and inorganic buffers were investigated using the temporarily-isolated and washed rumen in three sheep. Although the net absorption rate of ${ }^{24} \mathrm{Mg}$ from supernatant fractions or buffers containing similar $\mathrm{K}$ concentrations varied significantly between sheep, a similar percentage decrease in the absorption rates of both ${ }^{24} \mathrm{Mg}$ and ${ }^{28} \mathrm{Mg}$ was found for each sheep as the $\mathbf{K}$ concentration was increased.

7. One pair of sheep was fed on the frozen grass and the other pair was fed on the grass-maize pellets. Their daily intakes of $\mathrm{K}$ were then increased to $50 \mathrm{~g} / \mathrm{d}$ for $14 \mathrm{~d}$ by intrarumen infusion of potassium chloride. In three of the four sheep the plasma $\mathrm{Mg}$ concentration fell within $12 \mathrm{~h}$ of the start of the $\mathrm{KCl}$ administration. In all sheep urinary excretion of $\mathrm{Mg}$ decreased and its faecal output increased. The increased intake of $\mathrm{K}$ had no effect on the distribution of $\mathrm{Mg}$ in the rumen contents.

8. Gel-filtration chromatography of the $100000 \mathrm{~g}$ supernatant fractions, regardless of the diet, showed that over $90 \%$ of the $\mathrm{Mg}$ in the $100000 \mathrm{~g}$ supernatant fractions was associated with a low-molecular-weight fraction of about $200 \mathrm{Da}$ which corresponded to the elution volume of magnesium chloride in $0 \cdot 1 \mathrm{M}$-sodium chloride.

9. It is concluded that any binding of $\mathrm{Mg}$ ions to small organic molecules in the $100000 \mathrm{~g}$ supernatant fraction of rumen contents played no significant role in the restriction of $\mathrm{Mg}$ absorption from the reticulo-rumen. The depressent effect of increased $\mathrm{K}$ concentration in rumen contents on the net absorption of $\mathrm{Mg}$ is via a reduction in the absorptive flux rather than by increased secretion of $\mathrm{Mg}$ into the rumen fluid.

The continual absorption of magnesium by a saturable, energy-dependent process from the reticulo-rumen is crucial for the homeostatic control of $\mathrm{Mg}$ metabolism in sheep (Martens et al. 1978; Martens \& Rayssiguier, 1980; Martens, 1983). The main factors controlling Mg absorption appear to be its concentration in the liquid phase of the digesta, and changes in the rate of $\mathrm{Mg}$ transport through the rumen wall caused by factors such as dietary constituents, for example, potassium, (Field \& Munro, 1977; Field, 1983).

Present addresses: * Applied Biochemistry Division, Department of Scientific and Industrial Research, Palmerston North, New Zealand.

$\uparrow$ Department of Veterinary Clinical Sciences, University of Melbourne, Princes Highway, Werribee, Victoria 3030, Australia.

$\ddagger$ For reprints. 
There is little information on the distribution of $\mathrm{Mg}$ in the digesta in the reticulo-rumen, or of the forms of $\mathrm{Mg}$ present in the liquid phase (Field, 1983). It has been reported that $\mathrm{Mg}$ exists in an ultrafilterable form in the rumen (Storry, 1961), but it is unclear if this $\mathrm{Mg}$ is present as the free ion or associated with various molecules. Several binding substances including dietary lipids, bacterial cell walls, and other organic acid complexes such as tricarballylate have been proposed to explain the variation in $\mathrm{Mg}$ availability observed with different diets (Russell \& van Soest, 1984). Although they are now not considered to be important in the aetiology of acute hypomagnesaemia (Martens \& Rayssiguier, 1980; Field, 1983), few direct or quantitative measurements have been undertaken to examine the influence of binding or complexing of $\mathrm{Mg}$ in the liquid phase on the absorption of $\mathrm{Mg}$ from the rumen.

In the present study the distribution of $\mathrm{Mg}$ in reticulo-rumen contents was determined by differential centrifugation. The form of the $\mathrm{Mg}$ and the extent of its absorption from the $100000 \mathrm{~g}$ supernatant fractions taken from sheep fed on either frozen grass or a dried-grass and flaked-maize pelleted diet were also investigated. The possible association of $\mathrm{Mg}$ with other molecules in the $100000 \mathrm{~g}$ supernatant fraction was examined by gel-filtration chromatography, and the absorption of $\mathrm{Mg}$ from $100000 \mathrm{~g}$ supernatant fractions was studied using the temporarily-isolated and washed rumen technique (Martens \& Rayssiguier, 1980).

The well-known hypomagnesaemic effect associated with elevation of the intake of $\mathrm{K}$ (Sjollema, 1931) is considered to be caused by a reduction in the net absorption rate of $\mathrm{Mg}$ from the reticulo-rumen (Tomas \& Potter, 1976). Using the temporarily-isolated and washed rumen technique and ${ }^{28} \mathrm{Mg}$, we have re-examined the conclusion of Care et al. (1984) that this inhibitory effect of increased intrarumen $K$ concentration on the net absorption rate of $\mathrm{Mg}$ from a rumen pouch was the result of an increased rate of secretion of $\mathrm{Mg}$ ions into the pouch rather than a decrease in their rate of absorption.

\section{MATERIALS AND METHODS}

\section{Sheep}

Six crossbred sheep were each fitted with a rumen fistula. Three animals had a large fistula (120 $\mathrm{mm}$ diameter) and were used to measure $\mathrm{Mg}$ absorption by the temporarily-isolated and washed rumen technique. The other three animals had a small fistula ( $40 \mathrm{~mm}$ diameter) and were used for the $\mathrm{Mg}$ balance studies.

\section{Diet}

The frozen grass was harvested in May 1984 by cutting pasture at a height of $90-100 \mathrm{~mm}$ and packing into $25-\mathrm{kg}$ bags which were kept at $-20^{\circ}$. The pelleted dried-grass-maize diet was prepared from a 1:1 mixture of dried grass and flaked maize. The frozen grass, without thawing, and the grass-maize pellets were given twice daily at 09.00 and 17.00 hours to provide a total daily dry matter (DM) intake of 970 and $1070 \mathrm{~g}$ respectively. The mean concentrations of $\mathrm{Mg}$, calcium, sodium and $\mathrm{K}$ in the frozen grass were $2 \cdot 0,5 \cdot 4,4.4$ and $25.3 \mathrm{~g} / \mathrm{kg}$ DM respectively, and the corresponding values for the grass-maize pellets were $2 \cdot 2,5 \cdot 6,6 \cdot 2$ and $11 \cdot 0 \mathrm{~g} / \mathrm{kg} \mathrm{DM}$ respectively.

\section{Experimental design}

The sheep were randomly divided into two groups of three (two 'Bal' sheep and one 'Abs' sheep) so that one group was fed on the frozen grass and the other group the pelleted dried-grass-maize diet. The Bal sheep were used to determine the apparent absorption of $\mathrm{Mg}$ as well as providing rumen contents for investigating (a) the fractionation and distribution of $\mathrm{Mg}$ in the rumen contents, (b) the changes in the rumen concentrations of 
$\mathrm{Mg}, \mathrm{Ca}, \mathrm{Na}$ and $\mathrm{K}$ after feeding, and (c) the preparation of the $100000 \mathrm{~g}$ supernatant fraction needed for the $\mathrm{Mg}$ absorption studies using the temporarily-isolated and washed rumen technique with the Abs sheep. Likewise the Abs sheep also provided rumen contents for (a) the study on the fractionation and $\mathrm{Mg}$ distribution in rumen contents, and (b) the preparation of the $100000 \mathrm{~g}$ supernatant fraction for their $\mathrm{Mg}$ absorption studies.

A pre-experimental period of $10 \mathrm{~d}$ was followed by (a) a $12 \mathrm{~d}$ period when rumen contents were collected on $2 \mathrm{~d}$ from all sheep for the fractionation and $\mathrm{Mg}$ distribution studies on the rumen contents, as well as to prepare the $100000 \mathrm{~g}$ supernatant fraction for the $\mathrm{Mg}$ absorption studies using the washed rumen technique; (b) a $9 \mathrm{~d}$ balance study during which the $\mathrm{Mg}$ intake and its apparent absorption were determined using the Bal sheep. During this period the two Mg-absorption experiments using the Abs sheep were also carried out.

The previously-described procedures involving first the $12 \mathrm{~d}$ and then the $9 \mathrm{~d}$ experimental periods were then repeated, except that in this second $12 \mathrm{~d}$ period additional small subsamples $(400 \mathrm{~g})$ of rumen contents were collected over $3 \mathrm{~d}$ for a study on the changes in the concentrations in it of $\mathrm{Mg}, \mathrm{Na}, \mathrm{K}$ and $\mathrm{Ca}$ at 4, 8, 12 and $16 \mathrm{~h}$ after feeding. A fifth $\mathrm{Mg}$ absorption study was carried out at the end of the second $9 \mathrm{~d}$ balance study.

Alteration of rumen $K$ concentration by intrarumen infusion of potassium chloride

This was carried out using two Bal sheep per diet. Each sheep acted as it own control for a $25 \mathrm{~d}$ period before $\mathrm{KCl}$ was continuously infused intraruminally for a $14 \mathrm{~d}$ period. On days 6 and 7 of the control period $300-400 \mathrm{ml}$ rumen contents were removed $16 \mathrm{~h}$ after feeding to determine the $\mathrm{Mg}, \mathrm{Ca}, \mathrm{Na}$ and $\mathrm{K}$ concentrations. At days 8 and 12 about 2 litres of the rumen contents were removed to prepare the $100000 \mathrm{~g}$ supernatant fraction for the $\mathrm{Mg}$ absorption studies using the temporarily-isolated, emptied and washed rumen technique. The residue, largely undigested plant material, remaining after the preparation of the supernatant fraction, was added to buffer (rinsing buffer, Table 1 ), warmed to $39^{\circ}$ and returned to the rumen. To increase the supply of the $100000 \mathrm{~g}$ supernatant fraction, rumen contents were also collected from two extra sheep, one fed on frozen grass and the other grass-maize pellets. A $9 \mathrm{~d}$ balance study commenced at day 17 of the control period. Blood samples were taken at days 24 and 25 and continued for a further $7 \mathrm{~d}$.

At the end of the control period the $\mathrm{K}$ intake was increased to $50 \mathrm{~g} / \mathrm{d}$ for all sheep by intrarumen infusion of $\mathrm{KCl}$ in 2 litres water and continued for $14 \mathrm{~d}$. On days 4 and 5 after the infusion began, $300-400 \mathrm{ml}$ rumen contents were removed to determine the concentrations of $\mathrm{Mg}, \mathrm{Ca}, \mathrm{Na}$ and $\mathrm{K}$, and the distribution of $\mathrm{Mg}$. This was followed by a second $9 \mathrm{~d}$ balance study.

\section{Studies on $\mathrm{Mg}$ absorption from the rumen}

These experiments involved the use of the temporarily-isolated, emptied and washed rumen technique of Martens \& Rayssiguier (1980) to study the effect of varying the $\mathrm{K}$ concentration in the $100000 \mathrm{~g}$ supernatant fractions, and inorganic buffers, on the net absorption of $\mathrm{Mg}$. Two sheep fed on frozen grass and one fed on grass-maize pellets were used.

Sheep were only used for absorption experiments if their food intake was normal during the previous week, and if there had been no leakage from the large fistulas. Six absorption experiments were conducted on a sheep in $1 \mathrm{~d}$, and the minimum interval between repeating the procedure on the one sheep was $7 \mathrm{~d}$. Before each measurement of $\mathrm{Mg}$ absorption, the rumen wall was adapted to the experimental conditions by introducing 2 litres of the experimental solution, warmed to $39^{\circ}$, into the rumen for $20 \mathrm{~min}$. After removal of this solution by suction, another 2 litres of the experimental solution containing ${ }^{51} \mathrm{CrEDTA}$ (Amersham International plc, Amersham, Bucks) or ${ }^{14} \mathrm{C}$-labelled polyethylene glycol, 
Table 1. Composition of buffer solutions used in the magnesium absorption studies with the temporarily-isolated, emptied and washed rumen of sheep

\begin{tabular}{|c|c|c|c|c|}
\hline \multirow[b]{2}{*}{ Compound } & \multicolumn{4}{|c|}{ Concentration of compound in buffer solution* $(\mathrm{mmol} / \mathrm{l})$} \\
\hline & $\begin{array}{l}\text { Rinsing } \\
\text { buffer }\end{array}$ & $\begin{array}{c}\text { Low-potassium } \\
\text { buffer }\end{array}$ & $\begin{array}{l}\text { Medium-K } \\
\text { buffer }\end{array}$ & $\begin{array}{l}\text { High-K } \\
\text { buffer }\end{array}$ \\
\hline $\mathrm{NaCl}$ & 61 & 51 & 31 & 4 \\
\hline $\mathrm{NaHCO}_{3}$ & 25 & 25 & 15 & 7 \\
\hline $\mathrm{Na}_{2} \mathrm{HPO}_{4} \cdot 12 \mathrm{H}_{2} \mathrm{O}$ & 2 & 2 & 2 & 2 \\
\hline $\mathrm{KCl}$ & 10 & 10 & 30 & 55 \\
\hline $\mathrm{KHCO}_{3}$ & 20 & 20 & 30 & 35 \\
\hline Sodium acetate & 30 & 30 & 30 & 30 \\
\hline Propionic acid & 10 & 10 & 10 & 10 \\
\hline Butyric acid & 5 & 5 & 5 & 5 \\
\hline $\mathrm{MgCl}_{2} \cdot 6 \mathrm{H}_{2} \mathrm{O}$ & $2 \cdot 5$ & $2 \cdot 4$ & $2 \cdot 4$ & $2 \cdot 4$ \\
\hline $\mathrm{CaCl}_{2} \cdot 6 \mathrm{H}_{2} \mathrm{O}$ & 2 & $2 \cdot 8$ & $2 \cdot 8$ & $2 \cdot 8$ \\
\hline Glucose & 5 & 5 & 5 & 5 \\
\hline $\mathrm{NH}_{4} \mathrm{Cl}$ & - & 10 & 10 & 10 \\
\hline $\mathrm{Na}: \mathrm{K}$ & - & $100: 30$ & $80: 60$ & $45: 90$ \\
\hline
\end{tabular}

* $\mathrm{pH}$ after equilibration with carbon dioxide at $39^{\circ}$ was $6.6-6.8$.

molecular weight 4000 (PEG; Amersham International ple) was introduced. The solution was continually-gassed with carbon dioxide in the rumen via a tube fitted with a diffusing nozzle to maintain $\mathrm{pH}$ of the solution within the range 6.6-7.0 during the experiment. After $20 \mathrm{~min}$, a $10 \mathrm{ml}$ sample was taken and this was deemed to be taken at time zero. Further samples were taken 20,40 and 60 min later.

${ }^{28} \mathrm{Mg}$ (Institute of Nuclear Chemistry, Julich, Federal Republic of Germany) was added $(0.5 \mu \mathrm{Ci} / 1)$ to each buffer and supernatant fraction so that the $\mathrm{Mg}$ efflux from the rumen to the blood could be measured. The disappearance of ${ }^{24} \mathrm{Mg}$ from the rumen reflects the net $\mathrm{Mg}$ absorption from this organ after correction for net water movement using ${ }^{14} \mathrm{C}$-labelled PEG. The influx of $\mathrm{Mg}$ from the blood to the rumen can be calculated from the difference in these two variables. Changes in volume of fluid in the rumen were measured in the presence of ${ }^{28} \mathrm{Mg}$ by using the inert marker ${ }^{14} \mathrm{C}$-labelled PEG at a concentration of $5 \mu \mathrm{Ci} / 1$ with unlabelled PEG (1 g/l). In the absence of ${ }^{28} \mathrm{Mg},{ }^{51} \mathrm{CrEDTA}(3 \mu \mathrm{Ci} / \mathrm{l})$ was used. Since none of the experimental fluids used was likely to differ appreciably from isotonicity, no significant absorption of CrEDTA from the rumen would be expected (Dobson et al. 1976).

Two sheep were used for experiments comparing the absorption of $\mathrm{Mg}$ from supernatant fractions with that from inorganic buffers. The order of experimental solutions used in the sheep fed on frozen grass was as follows: $\mathrm{E}_{1}$, low-K high-Na buffer (Table 1); $\mathrm{E}_{2}$, high-K low-Na buffer (Table 1); $\mathrm{E}_{3}, 100000 \mathrm{~g}$ supernatant fraction from rumen contents of sheep $16 \mathrm{~h}$ after feeding frozen grass; $\mathrm{E}_{4}$, inorganic buffer with similar $\mathrm{Mg}, \mathrm{Ca}, \mathrm{Na}$ and $\mathrm{K}$ concentrations to this frozen-grass supernatant fraction; $\mathrm{E}_{5}, 100000 \mathrm{~g}$ supernatant fraction from rumen contents of sheep $16 \mathrm{~h}$ after feeding grass-maize pellets; $\mathrm{E}_{6}$, inorganic buffer with similar $\mathrm{Mg}, \mathrm{Ca}, \mathrm{Na}$ and $\mathrm{K}$ concentrations to this grass-maize pellet supernatant fraction. In the sheep fed on grass--maize pellets, experimental solutions $E_{5}$ and $E_{6}$ were examined before $E_{3}$ and $E_{4}$.

Values were obtained from experiments repeated five times on the sheep fed on frozen grass over a 7 week period, and three times on the sheep fed on grass-maize pellets over a 3 week period. Experimental solutions $E_{1}$ and $E_{2}$ were used on all sheep when absorption 
studies were carried out to act as a standard between studies and to check on the physiological validity of the technique. The rate of $\mathrm{Mg}$ absorption from $\mathrm{E}_{2}$ was always less than that from $\mathrm{E}_{1}$ as $\mathrm{K}$ inhibits $\mathrm{Mg}$ absorption. Results from $\mathrm{E}_{3}$ were compared with $\mathrm{E}_{4}$ and similarly $E_{5}$ with $E_{6}$ in an attempt to compare the absorption of $\mathrm{Mg}$ in either the presence or absence of potential $\mathrm{Mg}$-binding compounds capable of reducing the absorption rate of $\mathrm{Mg}$.

Three sheep were used for experiments where the effect of increasing $\mathrm{K}$ concentration on $\mathrm{Mg}$ absorption from experimental $100000 \mathrm{~g}$ supernatant fractions was examined. As the intrarumen infusion of $\mathrm{K}$ had a similar effect, regardless of diet or sheep, on the distribution and concentrations of $\mathrm{Mg}, \mathrm{Na}$ and $\mathrm{K}$ concentrations in the rumen contents and $100000 \mathrm{~g}$ supernatant fractions, the $100000 \mathrm{~g}$ supernatant fractions from all sheep were bulked to provide a pool of material for the $\mathrm{Mg}$ absorption studies. By addition of water, $\mathrm{KCl}$, or sodium chloride solutions to the bulked $100000 \mathrm{~g}$ supernatant fractions the experimental $100000 \mathrm{~g}$ supernatant fractions were prepared to contain $\mathrm{K}$ concentrations increasing from 30 to $90 \mathrm{mmol} / \mathrm{l}$ and $\mathrm{Na}$ concentrations decreasing from 100 to $45 \mathrm{mmol} / \mathrm{l}$.

The compositions of the low- $\mathrm{K}$, high-Na $100000 \mathrm{~g}$ supernatant fraction and the inorganic buffer were based on the $\mathrm{Mg}, \mathrm{Ca}, \mathrm{Na}$ and $\mathrm{K}$ concentrations observed in $100000 \mathrm{~g}$ supernatant fractions of the rumen contents collected during the control period of the first part of the study. The compositions of the medium-K and medium- $\mathrm{Na}$ $100000 \mathrm{~g}$ supernatant fraction and electrolyte buffers were based on the $\mathrm{Mg}, \mathrm{Ca}, \mathrm{Na}$ and $\mathrm{K}$ concentrations observed in the $100000 \mathrm{~g}$ supernatant fractions if the rumen contents collected during the period when $\mathrm{K}$ was being infused into the rumen of the sheep also used in the present study. In addition, a high-K, low-Na supernatant-fraction buffer was prepared to give $\mathrm{K}$ and $\mathrm{Na}$ concentrations similar to those found by Scott \& Dobson (1965) in the rumen contents of sheep which had developed hypomagnesaemic tetany when grazing pastures high in $\mathrm{K}$ and low in $\mathrm{Na}$. The experimental $100000 \mathrm{~g}$ supernatant fractions as well as being made up with the required amounts of $\mathrm{Mg}, \mathrm{Ca}, \mathrm{Na}$ and $\mathrm{K}$ were also reconstituted with ammonium acetate, glucose, propionic acid and butyric acid at concentrations similar to the low-, medium- and high-K buffers (Table 1).

The absorption studies on the three experimental $100000 \mathrm{~g}$ supernatant fractions and matching buffers were carried out over a $12 \mathrm{~h}$ interval (six $\times 2 \mathrm{~h}$ periods) in the isolated, washed rumen in three sheep. The order in which the supernatant fractions and buffers was studied was: period 1, low-K high-Na buffer; period 2, low-K high-Na supernatant fraction; period 3, medium-K medium-Na buffer; period 4 , medium-K medium- $\mathrm{Na}$ supernatant fraction; period 5, high-K low-Na buffer; period 6, high-K low-Na supernatant fraction.

Each solution was warmed to $39^{\circ}$, and gassed with carbon dioxide to bring the $\mathrm{pH}$ to between 6.6 and 6.8 . A volume of 2 litres was placed in the rumen for $20 \mathrm{~min}$ before the zero sample was collected. Further samples were collected at 20,40 and $60 \mathrm{~min}$. When changing to solutions containing high- $\mathrm{K}$ concentrations this solution was placed in the rumen for $30 \mathrm{~min}$ to allow the rumen absorptive surface to adapt to the experimental conditions before it was replaced by a fresh volume of high-K buffer or supernatant fraction from which absorption measurements were made.

Net efflux of $\mathrm{Mg}, A(\mu \mathrm{mol} / \mathrm{l}$ per $\mathrm{min})$, was calculated as follows:

$$
A=\frac{C_{1}-\left(C_{2} \times M_{1} / M_{2}\right)}{t}
$$

where $C_{1}$ is $\mathrm{Mg}$ concentration $(\mu \mathrm{mol} / 1)$ in rumen at time $0 ; C_{2}$ is $\mathrm{Mg}$ concentration $(\mu \mathrm{mol} /$ 1) in rumen fluid after time $t(\mathrm{~min}) ; M_{1}$ is concentration of ${ }^{51} \mathrm{CrEDTA}$ at time $0 ; M_{2}$ is concentration of ${ }^{51} \mathrm{CrEDTA}$ after $t(\mathrm{~min})$. 


\section{Fractionation of the rumen contents}

About $2 \mathrm{~kg}$ of the rumen contents were removed, a $400 \mathrm{~g}$ subsample taken and the remaining contents were immediately returned to the rumen. The subsample was first centrifuged at $20000 \mathrm{~g}$ for $0.5 \mathrm{~h}$ and the supernatant fraction collected. This was spun at $100000 \mathrm{~g}$ for a further $0.5 \mathrm{~h}$ and the supernatant fraction kept. The various fractions were weighed and subsamples taken for $\mathrm{Mg}$ analysis.

\section{Preparation of the $100000 \mathrm{~g}$ supernatant fraction}

About $2 \mathrm{~kg}$ of the rumen contents were collected $16 \mathrm{~h}$ after feeding from the Bal sheep as well as all the rumen contents from the Abs sheep just before their preparation for the $\mathrm{Mg}$ absorption studies. These rumen contents from all the sheep on a particular diet were then bulked and strained through a linen cloth. The residue containing the food particles was then immediately returned to the rumens of the Bal sheep and at the end of the $\mathrm{Mg}$ absorption study in the case of the Abs sheep, as reconstituted rumen contents since it was mixed with the rinsing buffer solution (Table 1) to replace the strained rumen fluid, and warmed to $39^{\circ}$. The $100000 \mathrm{~g}$ supernatant fraction was prepared from the strained rumen fluid by centrifuging at $100000 \mathrm{~g}$ for $60 \mathrm{~min}$. The supernatant fraction was kept at $4^{\circ}$ if needed within a few days or otherwise stored at $-10^{\circ}$.

\section{Gel filtration of the $100000 \mathrm{~g}$ supernatant fraction}

Sephadex G-15 was packed into a $240 \times 15 \mathrm{~mm}$ column giving a bed volume $\left(V_{\mathrm{t}}\right)$ of $42 \mathrm{ml}$. The column was eluted with water to give a flow-rate of $30 \mathrm{ml} / \mathrm{h}\left(17 \mathrm{ml} / \mathrm{cm}^{2}\right.$ per h). The void volume $\left(V_{0}\right)$ as determined by blue dextran was $17 \mathrm{ml}$ and the column was calibrated using L- $\beta$-phenylalanine (molecular weight 165 ; elution volume $\left(V_{\mathrm{e}}\right) 30 \mathrm{ml}$ ) and Ltryptophan (molecular weight $204 ; V_{\mathrm{e}} 26 \mathrm{ml}$ ). A $0.5 \mathrm{ml}$ sample of $100000 \mathrm{~g}$ supernatant fraction was placed on the column and $50 \mathrm{ml}$ of the eluant was collected in $1 \mathrm{ml}$ quantities.

The following solutions as $0.5 \mathrm{ml}$ portions were run on the column and with water:

(a) $100000 \mathrm{~g}$ supernatant fraction before the $\mathrm{Mg}$ absorption measurement;

(b) $100000 \mathrm{~g}$ supernatant fraction after the $\mathrm{Mg}$ absorption measurement in the rumen;

(c) $100000 \mathrm{~g}$ supernatant fraction $+50 \mu \mathrm{g} \mathrm{Mg}$ as $\mathrm{MgCl}_{2} \cdot 6 \mathrm{H}_{2} \mathrm{O}$;

(d) $100000 \mathrm{~g}$ supernatant fraction $+{ }^{28} \mathrm{Mg}(0.33 \mu \mathrm{Ci} / \mathrm{l})$;

(e) $100 \mu \mathrm{g} \mathrm{Mg}$ as $\mathrm{MgCl}_{2} \cdot 6 \mathrm{H}_{2} \mathrm{O}$ in $0.5 \mathrm{ml} 0 \cdot 1 \mathrm{M}-\mathrm{NaCl}$.

The organic material in the eluant was monitored by the absorbance at $280 \mathrm{~nm}$; the $\mathrm{Mg}$ concentration was measured by atomic absorption spectrophotometry.

\section{Analytical methods}

Samples of the diets were dried and ground, as were the fractions from the rumen contents, before dry ashing at $480^{\circ}$ for $12 \mathrm{~h}$. The ash was dissolved in $6 \mathrm{M}$-hydrochloric acid with warming and diluted in $0 \cdot 1 \mathrm{M}-\mathrm{HCl}$ for the $\mathrm{Mg}, \mathrm{Ca}, \mathrm{Na}$ and $\mathrm{K}$ analyses. Urine samples were diluted in $0 \cdot 1 \mathrm{M}-\mathrm{HCl}$ while samples of $100000 \mathrm{~g}$ supernatant fractions and solutions from the $\mathrm{Mg}$ absorption experiments were diluted with trichloracetic acid $(100 \mathrm{~g} / \mathrm{l})$ to give a 1:100 solution. $\mathrm{Mg}$ and $\mathrm{Ca}$ concentrations were determined by atomic absorption spectrophotometry on the acidified solutions containing $1 \mathrm{~g}$ lanthanum/1 while $\mathrm{Na}$ and $\mathrm{K}$ concentrations were determined by flame emission photometry. ${ }^{51} \mathrm{Cr}$ was counted in a welltype scintillation counter (Gamma Guard; Tracer Laboratories, Weybridge, Surrey). The measurement of ${ }^{14} \mathrm{C}$ in the PEG in the presence of ${ }^{28} \mathrm{Mg}$ was delayed for 2 weeks to allow complete decay of the ${ }^{28} \mathrm{Mg}$. The ${ }^{14} \mathrm{C}$-labelled PEG was counted by liquid scintillation 
Table 2. Mean daily intakes, excretion and apparent absorption ( $\mathrm{mg} / \mathrm{d})$ of magnesium determined from a 9 d balance study before and after continuous potassium infusion into the rumen of sheep fed on frozen grass and grass-maize pellets

\begin{tabular}{|c|c|c|c|c|c|c|}
\hline \multirow[t]{2}{*}{$\mathrm{K}$ intake } & \multicolumn{2}{|c|}{$22 \mathrm{~g} / \mathrm{d}\left(\mathrm{K}_{1}\right)$} & \multicolumn{2}{|c|}{$50 \mathrm{~g} / \mathrm{d}\left(\mathrm{K}_{2}\right)$} & \multicolumn{2}{|c|}{$\begin{array}{l}\text { Difference } \\
\left(\mathbf{K}_{2}-\mathbf{K}_{1}\right)\end{array}$} \\
\hline & \multicolumn{5}{|c|}{ Frozen grass diet } & \\
\hline Sheep no. & 5 & 6 & 5 & 6 & 5 & 6 \\
\hline $\mathrm{Mg}$ intake & 1785 & 1796 & 1785 & 1796 & 0 & 0 \\
\hline Faecal output & 1164 & 1291 & 1260 & 1330 & 96 & 39 \\
\hline Urinary excretion & 518 & 112 & 286 & 31 & -232 & -81 \\
\hline Apparent absorption & 621 & 505 & 525 & 466 & -96 & -39 \\
\hline \multirow[t]{2}{*}{ Intake $(\%)$} & 35 & 28 & 29 & 26 & & \\
\hline & \multicolumn{6}{|c|}{ Grass-maize pellet diet } \\
\hline Sheep no. & 3 & 4 & 3 & 4 & 3 & 4 \\
\hline $\mathrm{Mg}$ intake & 2330 & 2330 & 2330 & 2330 & 0 & 0 \\
\hline Faecal output & 1496 & 1442 & 1645 & 1462 & 149 & 20 \\
\hline Urinary excretion & 90 & 28 & 5 & 5 & -85 & -23 \\
\hline Apparent absorption & 834 & 888 & 685 & 868 & -149 & -20 \\
\hline Intake $(\%)$ & 36 & 38 & 29 & 37 & & \\
\hline
\end{tabular}

(LKB-Wallac Rackbeta, Stockholm, Sweden) after $1 \mathrm{ml}$ sample had been dispensed in $10 \mathrm{ml}$ scintillant (Bray, 1960).

The statistical significance of the difference between two treatment means for $\mathrm{Mg}$ absorption was determined from $t$ tests using the residual mean square of a three-way analysis of variance with the main effects being sheep, time and treatment (SPSS, 1986).

\section{RESULTS}

The effects of diet on daily intakes, excretion and apparent absorption of $\mathrm{Mg}$ The mean daily intakes, faecal output, urinary excretion and apparent absorption of $\mathrm{Mg}$ in sheep fed on frozen grass and grass-maize pellets are given in Table 2. The amounts of $\mathrm{Mg}$ apparently absorbed ranged from 505 to $621 \mathrm{mg} / \mathrm{d}$ for sheep fed on the frozen grass while the values for the sheep on the grass-maize diet were 788 and $834 \mathrm{mg} / \mathrm{d}$. Sheep 5 had a significantly greater urinary excretion of $\mathrm{Mg}(518 \mathrm{mg} / \mathrm{d})$.

The mean $\mathrm{Ca}, \mathrm{Na}$ and $\mathrm{K}$ daily intakes were 4.87, 5.93 and $22.2 \mathrm{~g} / \mathrm{d}$ and 6.02,6.67 and $11.8 \mathrm{~g} / \mathrm{d}$ for the sheep on the frozen grass and grass-maize pellets respectively.

Changes in the concentrations of $\mathrm{Mg}, \mathrm{Ca}, \mathrm{Na}$ and $\mathrm{K}$ in the rumen after feeding The changes in the concentrations of $\mathrm{Mg}, \mathrm{Ca}, \mathrm{Na}$ and $\mathrm{K}$ in the rumen contents at 4, 8, 12 and $16 \mathrm{~h}$ after feeding are illustrated in Fig. 1. For both diets the changes in the concentrations of $\mathrm{Ca}$ and $\mathrm{K}$ were small over the $16 \mathrm{~h}$ period after feeding. However the concentrations of $\mathrm{Mg}$ significantly decreased and $\mathrm{Na}$ significantly increased between 4 and $16 \mathrm{~h}$ after feeding. The concentration ratio, $\mathrm{Na}: \mathrm{K}$ increased from 2.2 to 3.6 and from 2.7 to 4.3 in rumens of sheep fed on the frozen grass and grass-maize pellet diet respectively.

The distribution of $\mathrm{Mg}$ in the rumen contents

The distribution of $\mathrm{Mg}$ in the rumen contents at 4 and $16 \mathrm{~h}$ after feeding, with the $\mathrm{Mg}$ in each fraction being expressed as a percentage of the total $\mathrm{Mg}$ in the rumen contents, is shown in Fig. 2. Approximately 50 and $60 \%$ of the $\mathrm{Mg}$ in the rumen contents of both diets 


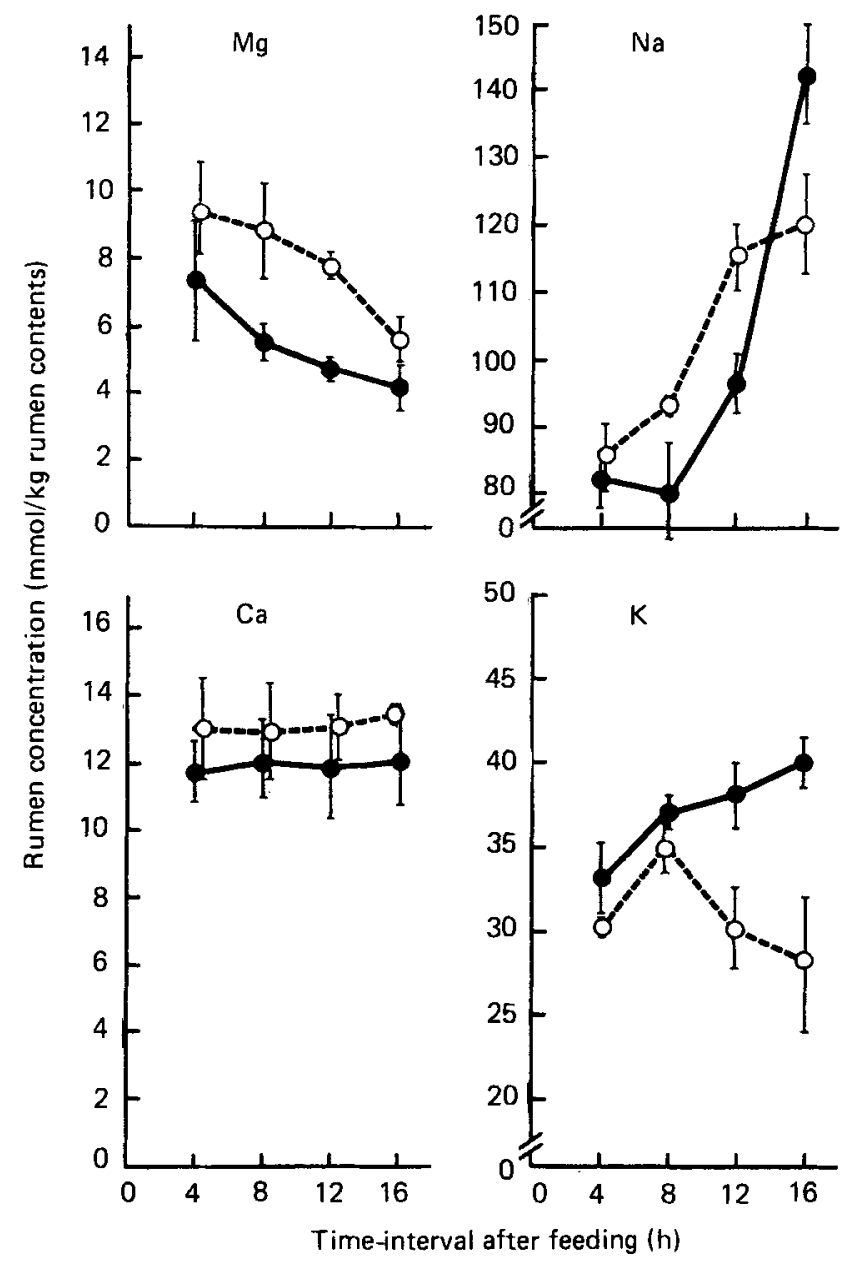

Fig. 1. Mean concentrations (mmol/kg contents) of magnesium, calcium, sodium and potassium in the ashed rumen contents at 4,8,12 and $16 \mathrm{~h}$ after sheep were fed on either frozen grass $(-\infty)$ or grass - maize pellets $(\mathrm{O}-\mathrm{O})$. Points are mean values with their standard errors represented by vertical bars.

was found to be associated with the strained rumen fluid at 4 and $16 \mathrm{~h}$ after feeding respectively. The $\mathrm{Mg}$ associated with the $100000 \mathrm{~g}$ supernatant fraction, regardless of diet, increased from approximately 31 to $38 \%$ as the time-interval after feeding increased ( $4 v$. $16 \mathrm{~h})$.

The mean amounts of $\mathrm{Ca}, \mathrm{Na}$ and $\mathrm{K}$ associated with the $100000 \mathrm{~g}$ supernatant fraction, expressed as a percentage of the total in the rumen contents, were 10, 58 and $43 \%$ respectively, and were similar for both diets.

The gel filtration profiles of the $100000 \mathrm{~g}$ supernatant fractions

The elution profiles of (a) the $100000 \mathrm{~g}$ supernatant fraction, and (b) the $100000 \mathrm{~g}$ supernatant fraction plus $\mathrm{MgCl}$ on Sephadex G-15 column are shown in Fig. 3. As there were no significant dietary effects on the profiles only the values for the frozen grass are given.

The major organic peak had a $V_{\mathrm{e}}$ of $17 \mathrm{ml}$ and a smaller peak with a $V_{\mathrm{e}}$ of $30 \mathrm{ml}$. As 


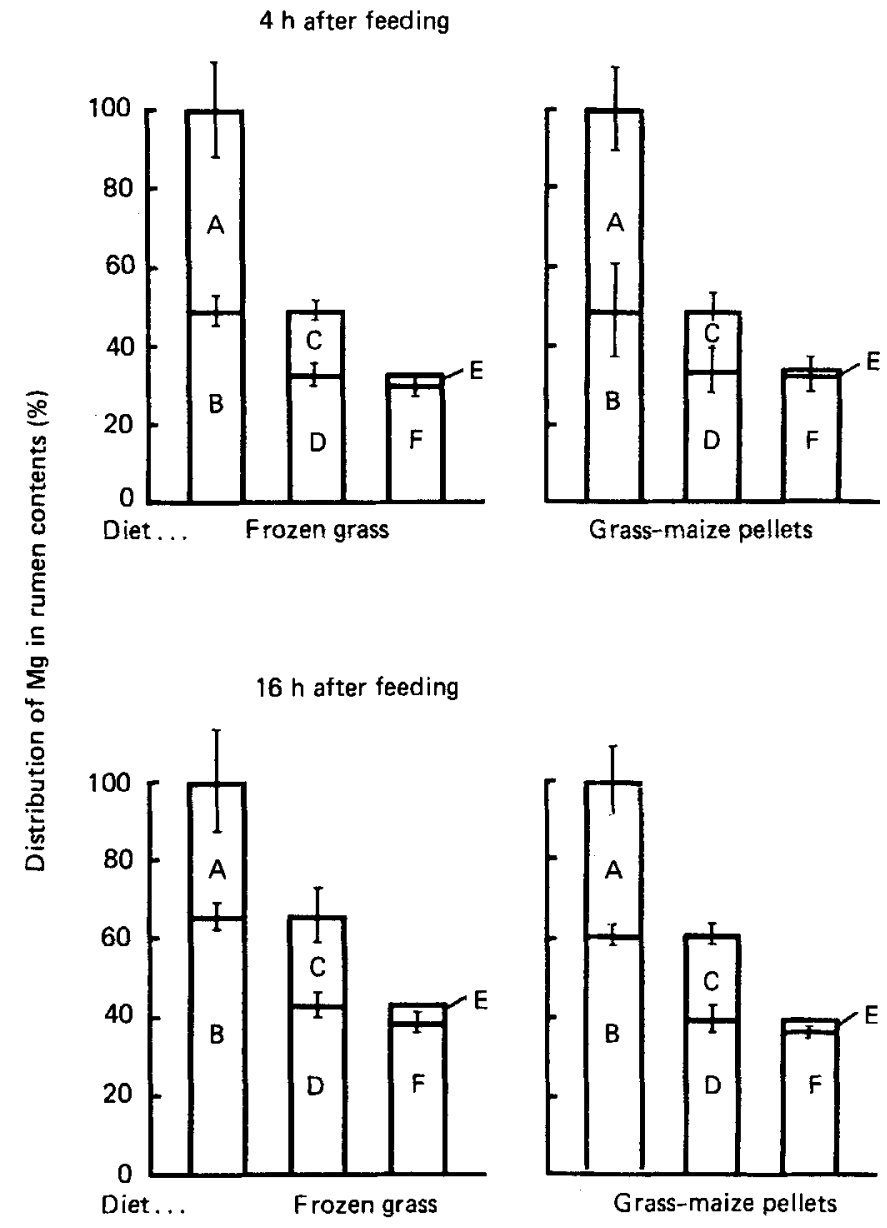

Fig. 2. The distribution of magnesium, expressed as a percentage of the total $\mathrm{Mg}$, between various fractions from the rumen contents of sheep fed on frozen grass and on grass-maize pellets: (A), strained rumen particles; (B), strained rumen fluid; (C), $20000 \mathrm{~g}$ pellet; (D), $20000 \mathrm{~g}$ supernatant fraction; (E), $100000 \mathrm{~g}$ pellet; (F), $100000 \mathrm{~g}$ supernatant fraction. Values are means with their standard errors represented by vertical bars.

$V_{\mathrm{o}}$ for the G-15 column was $17 \mathrm{ml}$ the first and largest peak reflects the organic material with a molecular weight of greater than $1500 \mathrm{Da}$. The molecular weight of the organic material in the smaller peak was determined to be about $120 \mathrm{Da}$ from the $V_{\mathrm{e}}$ for L- $\beta$ phenylalanine and L-tryptophan.

The $\mathrm{Mg}$ appeared between the two peaks $\left(V_{\mathrm{e}} 27 \mathrm{ml}\right)$. About $90 \%$ of the total $\mathrm{Mg}$ in the $0.5 \mathrm{ml}$ sample of $100000 \mathrm{~g}$ supernatant fraction placed on the column was recovered in tube nos. 22-32. A similar profile was obtained when ${ }^{28} \mathrm{Mg}$ labelled $100000 \mathrm{~g}$ supernatant fraction was run on the column. When $50 \mu \mathrm{g} \mathrm{Mg}$ as $\mathrm{MgCl}_{2} \cdot 6 \mathrm{H}_{2} \mathrm{O}$ was added to the $100000 \mathrm{~g}$ supernatant fraction, left for several hours and run on the column, over $90 \%$ of the added $\mathrm{Mg}$ was recovered in tube nos. 22-32 (Fig. 3). A peak of $\mathrm{Mg}$ concentration similar to that eluted for the $100000 \mathrm{~g}$ supernatant fraction was observed when $100 \mu \mathrm{g} \mathrm{Mg}$ as $\mathrm{MgCl}_{2} \cdot 6 \mathrm{H}_{2} \mathrm{O}$ in $0 \cdot 1 \mathrm{M}-\mathrm{NaCl}$ was placed on the column to produce an ionic strength similar to that of the $100000 \mathrm{~g}$ supernatant fraction. 


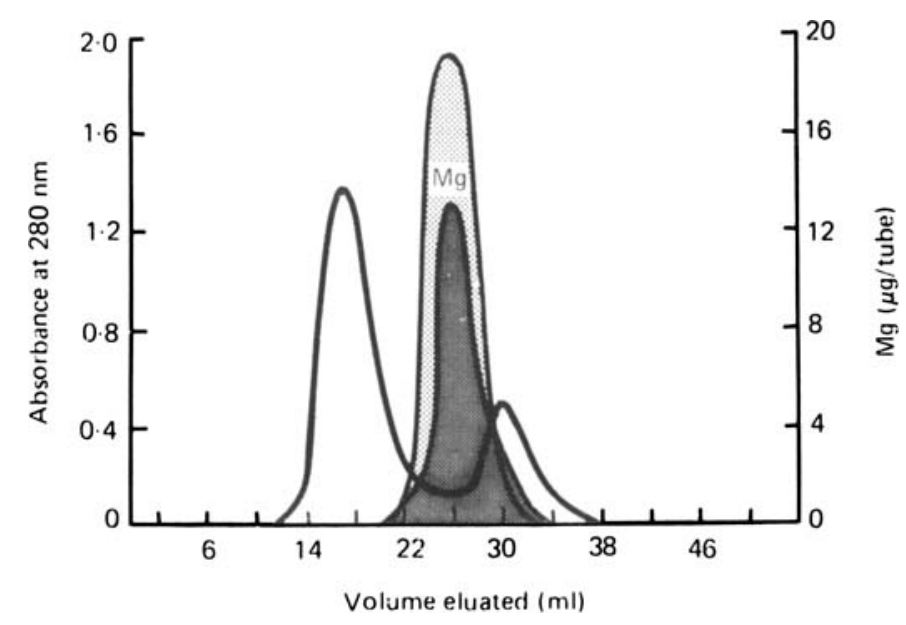

Fig. 3. The elution profile on a Sephadex G-15 column $(240 \times 15 \mathrm{~mm}$; equilibrated with water $)$ for the separation of organic substances and magnesium in the $100000 \mathrm{~g}$ supernatant fractions from sheep fed on frozen grass. ( $\mathbf{\square}) 100000 \mathrm{~g}$ supernatant fraction (圆) $100000 \mathrm{~g}$ supernatant fraction $+50 \mu \mathrm{g} \mathrm{Mg}$ as $\mathrm{MgCl}_{2} \cdot 6 \mathrm{H}_{2} 0$, (-) absorbance $280 \mathrm{~nm}$.

$M g$ absorption from the temporarily-isolated, washed reticulo-rumen

In two sheep fed on either frozen grass or grass-maize pellets, the absorption rates of $\mathrm{Mg}$ from 2 litres of a high- $\mathrm{Na}$ low-K buffer placed in the emptied rumen were significantly higher $(P<0.001)$ than those from a low-Na high-K buffer $(10.34 \nu .4 .41 \mu \mathrm{mol} / 1 \mathrm{per}$ min $)$ (Table 3). The Mg concentrations in the buffer were similar. The use of these buffers (Table 1) at the beginning of each series of experiments enabled the variation in $\mathrm{Mg}$ absorption by the rumen between study periods to be assessed. As there were no significant differences in the absorption rates of $\mathrm{Mg}$ from the same buffers or supernatants fractions used in the two sheep, the values obtained for each experimental solution have been pooled (Table 3).

The rates of absorption of $\mathrm{Mg}$ from $100000 \mathrm{~g}$ supernatant fractions prepared from rumen contents of sheep fed on either frozen grass or grass-maize pellets were not significantly different from corresponding inorganic buffers containing similar $\mathrm{Mg}, \mathrm{Na}, \mathrm{K}$ and $\mathrm{Ca}$ concentrations (Table 3). The concentrations of $\mathrm{Mg}$ in the $100000 \mathrm{~g}$ supernatant fractions varied between different preparations made over the experimental period, and those from sheep fed on the grass-maize pellets were consistently higher. The mean rate of net $\mathrm{Mg}$ absorption from the $100000 \mathrm{~g}$ supernatant fraction of rumen contents from sheep fed on grass-maize pellets was significantly higher $(P<0.05)$ than that from the 100000 $g$ supernatant fraction from sheep given frozen grass $(11.33 v .7 .31 \mu \mathrm{mol} \mathrm{Mg} / 1$ per min). The efficiency of the net absorption rate of $\mathrm{Mg}$ was also higher from the grass-maize-pellet supernatant fraction $(24.6$ v. 20.3\%/h).

\section{The effects of an increase in $K$ intake}

(a) Plasma $\mathrm{Mg}$ concentration. The effect of increasing the $\mathrm{K}$ intake to $50 \mathrm{~g} / \mathrm{d}$ on plasma $\mathrm{Mg}$ was complex as the $\mathrm{Mg}$ concentrations decreased within $12 \mathrm{~h}$ in both sheep fed on grass-maize pellets, but in only one of the sheep fed on frozen grass (Fig. 4). The decreases in plasma $\mathrm{Mg}$ ranged from 0.2 to $0.3 \mathrm{mmol} \mathrm{Mg} / 1$. The sheep did not become severely hypomagnesaemic or show signs of tetany, and the minimum plasma $\mathrm{Mg}$ concentration measured was $0.68 \mathrm{mmol} / 1$. 
Table 3. Magnesium concentrations in experimental solutions, and the absorption of $\mathrm{Mg}$ from the temporarily-isolated and washed rumen of sheep

(Mean values with their standard errors for five separate absorption studies on one sheep fed on frozen grass and three studies on one sheep fed on grass-maize pellets)

\begin{tabular}{|c|c|c|c|c|c|c|c|c|}
\hline \multirow{2}{*}{\multicolumn{2}{|c|}{ Solution }} & \multirow{2}{*}{$\begin{array}{l}\text { No. of } \\
\text { observations }\end{array}$} & \multicolumn{2}{|c|}{$\begin{array}{l}\mathrm{Mg} \text { concentration* } \\
(\mathrm{mmol} / \mathrm{l})\end{array}$} & \multicolumn{2}{|c|}{$\begin{array}{c}\text { Mg absorption } \\
(\mu \mathrm{mol} / 1 \text { per } \mathrm{min})\end{array}$} & \multicolumn{2}{|c|}{$\begin{array}{c}\text { Efficiency of net } \\
\mathrm{Mg} \text { absorption } \\
(\% / \mathrm{h})\end{array}$} \\
\hline & & & Mean & $\mathrm{SE}$ & Mean & $\mathrm{SE}$ & Mean & SE \\
\hline $\mathrm{E}_{1}$ & $\begin{array}{l}\text { Low-potassium high- } \\
\text { sodium buffer }\end{array}$ & 8 & $2 \cdot 64$ & 0.12 & $10 \cdot 34$ & 0.93 & $22 \cdot 6$ & $2 \cdot 9$ \\
\hline $\mathrm{E}_{2}$ & $\begin{array}{l}\text { High-K low-Na } \\
\text { buffer }\end{array}$ & 8 & 2.75 & $0 \cdot 16$ & $4 \cdot 41$ & 0.23 & $9 \cdot 1$ & $0 \cdot 7$ \\
\hline $\mathrm{E}_{\mathrm{a}}$ & $\begin{array}{l}100000 \mathrm{~g} \text { supernatant } \\
\text { fraction from frozen } \\
\text { grass (FG) }\end{array}$ & 7 & $2 \cdot 07$ & 0.23 & $7 \cdot 31$ & $1 \cdot 01$ & $20 \cdot 3$ & $2 \cdot 3$ \\
\hline$E_{4}$ & $\begin{array}{l}\text { Inorganic buffer with } \\
\text { similar macro- } \\
\text { element composition } \\
\text { to FG } 100000 \mathrm{~g} \\
\text { supernatant fraction }\end{array}$ & 6 & $2 \cdot 21$ & 0.20 & 7.73 & $1 \cdot 37$ & $21 \cdot 3$ & 3.0 \\
\hline $\mathrm{E}_{5}$ & $\begin{array}{l}100000 \mathrm{~g} \\
\text { supernatant fraction } \\
\text { from grass-maize pellet } \\
\text { (GP) }\end{array}$ & 7 & $2 \cdot 34$ & 0.42 & $11 \cdot 33$ & $2 \cdot 18$ & $24 \cdot 6$ & $6 \cdot 1$ \\
\hline $\mathrm{E}_{6}$ & $\begin{array}{l}\text { Inorganic buffer with } \\
\text { similar macroelement } \\
\text { composition } \\
\text { to GP } 100000 \mathrm{~g} \\
\text { supernatant fraction }\end{array}$ & 6 & $2 \cdot 74$ & 0.45 & 9.38 & 1.75 & $25 \cdot 6$ & $7 \cdot 5$ \\
\hline
\end{tabular}

* Mean concentration of $\mathrm{Mg}$ in reticulo-rumen during an $80 \mathrm{~min}$ period; absorption was measured during the final $60 \mathrm{~min}$ of this period.

Statistical significance of difference between mean $\mathrm{Mg}$ absorption rates: $\mathrm{E}_{1} v . \mathrm{E}_{2} P<0.001, \mathrm{E}_{5} v . \mathrm{E}_{3} P<0.05$, $\mathrm{E}_{3} v . \mathrm{E}_{4}$ and $\mathrm{E}_{5} v . \mathrm{E}_{6}$ not significant.

(b) The faecal and urinary excretion of $\mathrm{Mg}$. The increased $\mathrm{K}$ intake increased the faecal excretion of $\mathrm{Mg}$ and decreased urinary $\mathrm{Mg}$ output in all sheep studied regardless of diet (Table 2).

The $\mathrm{Mg}$ balance of sheep no. 5 was markedly different from the other sheep as it excreted large amounts of $\mathrm{Mg}$ in the urine. In this sheep, plasma $\mathrm{Mg}$ concentration did not decrease when $\mathrm{K}$ was infused into the rumen (Fig. 4).

(c) The $\mathrm{Mg}, \mathrm{Ca}, \mathrm{Na}$ and $\mathrm{K}$ concentrations in the rumen contents. The $\mathrm{K}$ infusion did not affect the concentrations of $\mathrm{Ca}$ and $\mathrm{Mg}$ in $100000 \mathrm{~g}$ supernatant fractions of rumen contents. For example, the $\mathrm{Mg}$ concentration in the $100000 \mathrm{~g}$ supernatant fraction from sheep fed on frozen grass and infused with $\mathrm{KCl}$ was 3.00 (SE 0.04) $\mathrm{mmol} / 1$ relative to the control value of 2.60 (SE 0.27 ) $\mathrm{mmol} / \mathrm{l}$. With sheep fed on the grass-maize pellets the comparable values were 3.50 (SE 0.52) and 3.20 (SE 0.25) mmol/1 respectively. All values are means of analyses of two collections made for each of two sheep. However, the $\mathrm{K}$ infusion caused the $\mathrm{K}$ concentration, regardless of the diet, to increase two- to three-fold while the $\mathrm{Na}$ concentration was decreased to about half the value of the control periods in the $100000 \mathrm{~g}$ supernatant fractions. 

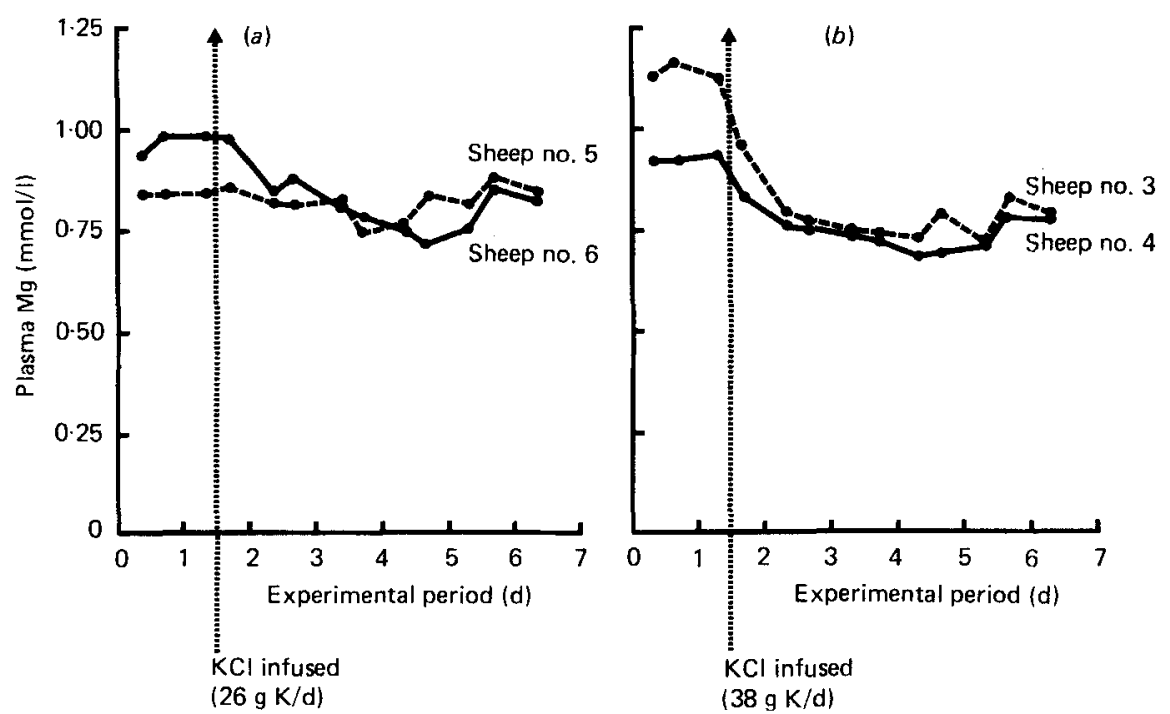

Fig. 4. Changes in plasma magnesium concentration following the start of an intrarumen infusion of potassium chloride in sheep fed on $(a)$ frozen grass or $(b)$ grass-maize pellets to increase potassium intake to $50 \mathrm{~g} \mathrm{~K} / \mathrm{d}$.

(d) The distribution of $\mathrm{Mg}$ in rumen contents. Intrarumen infusion of $\mathrm{KCl}$ had no effect on the distribution of $\mathrm{Mg}$ in the rumen contents of sheep fed on different diets. About $36-39 \%$ of the $\mathrm{Mg}$ in the rumen contents was found to be associated with the $100000 \mathrm{~g}$ supernatant fraction, and there were no apparent differences between supernatant fractions of rumen contents prepared from sheep fed on the different diets.

\section{Effect of increasing $K$ concentration on absorption of $M g$ from supernatant fractions and buffers in the rumen}

The net rate of absorption ( $\mu \mathrm{mol} / 1$ per $\mathrm{min}$ ) of $\mathrm{Mg}$ from $100000 \mathrm{~g}$ supernatant fractions and buffers in the isolated, washed rumens decreased in the three sheep as $\mathrm{K}$ concentrations increased (Fig. 5). Within a $\mathrm{K}$ concentration the differences between sheep in the net rates of $\mathrm{Mg}$ absorption were significant $(P<0.01)$. Furthermore, within an individual sheep, increasing the $\mathrm{K}$ concentrations significantly decreased the net $\mathrm{Mg}$ absorption rates. Values were similar for $100000 \mathrm{~g}$ supernatant fractions and buffers. The magnitudes of the differences in the rate of $\mathrm{Mg}$ absorbed were similar when comparing one sheep with another for a given concentration of $\mathrm{K}$ or when the intraruminal concentration of $\mathrm{K}$ was changed in an individual sheep.

The absorption rates of ${ }^{24} \mathrm{Mg}$ and ${ }^{28} \mathrm{Mg}$ were expressed as a percentage of the ${ }^{24} \mathrm{Mg}$ and ${ }^{28} \mathrm{Mg}$ absorbed from the total initial amounts of each isotope placed in the rumen at the beginning of the absorption periods (Table 4). Although there was no significant differences between the mean percentage of ${ }^{24} \mathrm{Mg}$ and ${ }^{28} \mathrm{Mg}$ atsorbed from the $100000 \mathrm{~g}$ supernatant fractions or the buffers containing similar concentrations of $K$, there were large differences between sheep as indicated by the SE values in Table 4 .

When values for buffers and supernatant fractions containing similar concentrations were pooled, there were significant and similar decreases in the percentages of ${ }^{24} \mathrm{Mg}$ and ${ }^{28} \mathrm{Mg}$ absorbed as the $\mathrm{K}$ concentration was increased $(P<0.05$, Table 4). This indicated that there were no apparent differences between the rates of ${ }^{24} \mathrm{Mg}$ and ${ }^{28} \mathrm{Mg}$ absorption as intrarumen $\mathrm{K}$ concentration was gradually increased. 


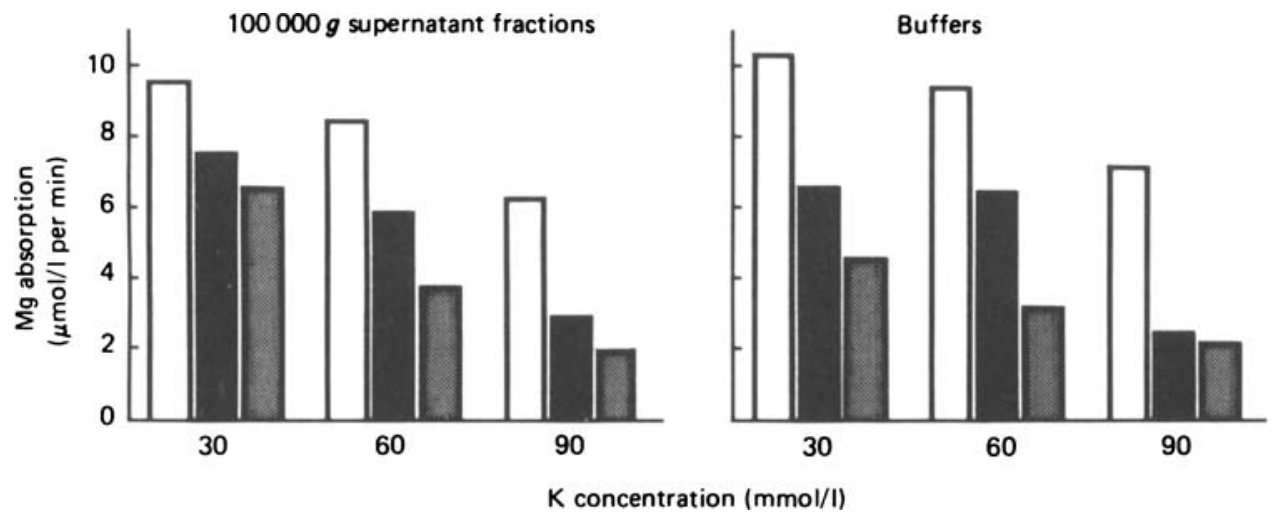

Fig. 5. Mean net magnesium absorption by the washed rumens of three sheep ( $\square$; $\square$; 圈) from $100000 \mathrm{~g}$ supernatant fractions and buffers containing different potassium and sodium concentrations (for details, see Table 1).

\section{DISCUSSION}

The concentration of $\mathrm{Mg}$ in the liquid phase of the rumen contents is an important factor which influences the rate of $\mathrm{Mg}$ absorption from the reticulorumen (Field, 1983). $\mathrm{Mg}$ is absorbed by an active, energy-dependent process which becomes saturated at a $\mathrm{Mg}$ concentration of $5 \mathrm{mmol} / 1$ (Brown et al. 1978; Martens, 1979). Therefore any factor which reduces the concentration of $\mathrm{Mg}$ ions at the absorptive site will adversely affect the rate of $\mathrm{Mg}$ absorption.

Rumen contents are a heterogeneous mixture of food particles, micro-organisms and organic and inorganic molecules. As $\mathrm{Mg}$ can bind to many organic molecules (Molloy \& Richards, 1971), the $\mathrm{Mg}$ content of the rumen contents is unlikely to represent the concentration of $\mathrm{Mg}$ ions at the absorptive sites on the rumen wall. However the 100000 $g$ supernatant fractions, which accounted for $30-38 \%$ of the total $\mathrm{Mg}$ in the rumen contents, contains no dietary particles or cellular debris but soluble inorganic or organic substances including $\mathrm{Mg}$, presumably in a form suitable for absorption.

The gel-filtration studies showed that both the $\mathrm{Mg}$ incorporated in and the $\mathrm{Mg}$ added to the $100000 \mathrm{~g}$ supernatant fraction were associated with a fraction which had a $V_{\mathrm{e}}$ which corresponded to a molecular weight of about $200 \mathrm{Da}$. The $\mathrm{Mg}$ in the low-molecular-weight fraction must be associated with other molecules. These may consist merely of an hydration shell since $\mathrm{Mg}$ ions were eluted from an aqueous solution in the same position.

The temporarily-isolated and washed rumen preparation was used to quantify the efficiency of absorption of $\mathrm{Mg}$, and the possible effect on it of an association of $\mathrm{Mg}$ with the organic material in the $100000 \mathrm{~g}$ supernatant fraction. The $\mathrm{Mg}$ was readily absorbed from the $100000 \mathrm{~g}$ supernatant fraction, regardless of the diet, and the presence of the organic substances in the supernatant fraction had no depressant effect on the efficiency of $\mathrm{Mg}$ absorption from the reticulo-rumen because a similar absorption rate was obtained using the electrolyte-buffer solutions which contained the same concentrations of $\mathrm{Mg}$ and other relevant macroelements as present in their matching $100000 \mathrm{~g}$ supernatant fractions.

The results of these gel filtration and rumen absorption studies suggest that any binding of $\mathrm{Mg}$ ions to organic moieties in the supernatant fraction obtained after $100000 \mathrm{~g}$ centrifugation of rumen contents is unlikely to play an important role in the restriction of $\mathrm{Mg}$ absorption from the recitulo-rumen.

It has been suggested that because $\mathrm{Mg}$ has a high binding affinity for various organic substances that this is an important factor, along with increasing dietary $\mathrm{K}$ levels, in 
Table 4. Absorption of ${ }^{24} \mathrm{Mg}$ and ${ }^{28} \mathrm{Mg}$, expressed as a percentage of the initial amount of $\mathrm{Mg}$ added, by the temporarily-isolated and washed rumen from $100000 \mathrm{~g}$ supernatant fractions and buffers containing different potassium concentrations

(Mean values with their standard errors)

\begin{tabular}{|c|c|c|c|c|c|c|c|c|c|}
\hline & & \multicolumn{4}{|c|}{${ }^{24} \mathrm{Mg}$ absorption (\%) } & \multicolumn{4}{|c|}{${ }^{28} \mathrm{Mg}$ absorption $\dagger(\%)$} \\
\hline \multicolumn{2}{|c|}{$\begin{array}{l}\text { K concentration* } \\
(\mathrm{mmol} / \mathrm{l})\end{array}$} & \multicolumn{2}{|c|}{$\begin{array}{l}100000 \mathrm{~g} \\
\text { supernatant fraction } \dagger\end{array}$} & \multicolumn{2}{|c|}{ Buffer } & \multicolumn{2}{|c|}{$\begin{array}{c}100000 \mathrm{~g} \\
\text { supernatant fraction } \dagger\end{array}$} & \multicolumn{2}{|c|}{ Buffer } \\
\hline Mean & $\mathrm{SE}$ & Mean & $\mathrm{SE}$ & Mean & $\mathrm{SE}$ & Mean & $\mathrm{SE}$ & Mean & SE \\
\hline $30 \cdot 5$ & $1 \cdot 4$ & $18 \cdot 0$ & $3 \cdot 5$ & $16 \cdot 4$ & $3 \cdot 4$ & $17 \cdot 8$ & 6.9 & $20 \cdot 5$ & $2 \cdot 5$ \\
\hline $60 \cdot 5$ & 1.9 & $13 \cdot 3$ & $7 \cdot 6$ & $13 \cdot 4$ & $5 \cdot 6$ & $12 \cdot 6$ & 3.9 & $12 \cdot 2$ & $4 \cdot 5$ \\
\hline $87 \cdot 8$ & 17 & $7 \cdot 9$ & $3 \cdot 8$ & $9 \cdot 9$ & 49 & $10 \cdot 1$ & $4 \cdot 1$ & 9.0 & $4 \cdot 5$ \\
\hline
\end{tabular}

* Mean $\mathrm{K}$ concentration during the $1 \mathrm{~h}$ absorption period.

+ Values are means from $1 \mathrm{~h}$ absorption periods with three sheep.

predisposing ruminants to hypomagnesaemia. However, in the present study it has been observed that the $\mathrm{Mg}$ which was readily absorbed from the rumen contents is probably hydrated $\mathrm{Mg}$ ions, although the possibility that it is also associated with a low-molecularweight organic fraction cannot be eliminated. Certainly such a fraction has no effect on the absorption of $\mathrm{Mg}$ from the reticulo-rumen.

The mean rates of net absorption of $\mathrm{Mg}$ from the $100000 \mathrm{~g}$ supernatant fractions were 7.3 and $11.3 \mu \mathrm{mol} / 1$ per min for sheep fed on frozen grass and grass-maize pellets respectively. The physiological effectiveness of the temporarily-isolated and washed rumen to absorb $\mathrm{Mg}$ was assessed by comparing the absorption rates, expressed as $\mathrm{mg} \mathrm{Mg} / \mathrm{d}$, with the apparent $\mathrm{Mg}$ absorption values of sheep fed on the same diets, as the rumen is the major site of $\mathrm{Mg}$ absorption in sheep (Grace et al. 1974; Grace, 1983). Assuming that at least 2 litres of the $100000 \mathrm{~g}$ supernatant fraction bathes the absorptive areas of the rumen then the mean amounts of $\mathrm{Mg}$ absorbed from the temporarily-isolated washed rumen were estimated to be 505 and $781 \mathrm{mg} / \mathrm{d}$ for the sheep fed on the frozen grass and grass-maize diets respectively. These values compare favourably with the mean amounts of $\mathrm{Mg}$ apparently absorbed, namely $563 \mathrm{mg} / \mathrm{d}$ for sheep fed on frozen grass and $811 \mathrm{mg} / \mathrm{d}$ for sheep fed on the grass-maize diet. The amounts of $\mathrm{Mg}$ absorbed are also adequate in terms of meeting the $\mathrm{Mg}$ requirements of the sheep. A $50 \mathrm{~kg}$ lactating ewe producing $2 \mathrm{~kg}$ milk/d has a net $\mathrm{Mg}$ requirement of approximately $500 \mathrm{mg} \mathrm{Mg} / \mathrm{d}$ (Agricultural Research Council, 1980).

The decrease in plasma $\mathrm{Mg}$ concentration, and reduced urinary and increased faecal $\mathrm{Mg}$ outputs observed following $\mathrm{K}$ infusion into the rumen are in agreement with earlier studies on sheep (Tomas \& Potter, 1976). Increased $\mathrm{K}$ intake has not always been associated with a reduction in plasma $\mathrm{Mg}$ in ruminants, and it has been suggested that any effect of $\mathrm{K}$ on $\mathrm{Mg}$ homeostasis is dependent on the level of Mg intake (Suttle \& Field, 1967, 1969; Field \& Suttle, 1979). The diets given to the sheep in the present study provided from 1.7 to $2.3 \mathrm{~g} \mathrm{Mg} / \mathrm{d}$, which was in excess of their requirements (Agricultural Research Council, 1980). Nevertheless, a depressant effect of $\mathrm{K}$ on $\mathrm{Mg}$ homeostasis was apparent to some degree in all our sheep.

The $\mathrm{KCl}$ infusions were associated with increased $\mathrm{K}$ and decreased $\mathrm{Na}$ concentrations in the $100000 \mathrm{~g}$ supernatant fractions from the rumen contents of sheep fed on both diets. The distribution and concentrations of $\mathrm{Mg}$ in the rumen contents, and proportion of $\mathrm{Mg}$ in the 
$100000 \mathrm{~g}$ supernatant fractions of rumen fluid did not change significantly as $\mathrm{K}$ concentrations increased. Although the $\mathrm{Mg}$ was absorbed from the $100000 \mathrm{~g}$ supernatant fractions at rates similar to those from inorganic buffers containing similar concentrations of $\mathrm{Mg}$ and other electrolytes, the net absorption of $\mathrm{Mg}$ from the rumen decreased as the $\mathrm{K}$ concentration was increased. It was therefore concluded that the effects of increased $\mathrm{K}$ intake on $\mathrm{Mg}$ metabolism were not due to decreased rates of release of $\mathrm{Mg}$ from the diet, altered distribution of $\mathrm{Mg}$ in rumen contents, or a decrease in the concentrations of $\mathrm{Mg}$ in rumen fluid, but were due to a decrease in the movement of $\mathrm{Mg}$ across the reticulo-rumen wall in response to the increased intrarumen $\mathrm{K}$ concentration.

$\mathrm{Mg}$ transport across the rumen epithelium has been associated with an active process linked to $\mathrm{Na}$ transport mediated by $\mathrm{Na}^{+}, \mathrm{K}^{+}$-ATPase activity on the serosal surface (Martens et al. 1978). The use of ${ }^{28} \mathrm{Mg}$ in $100000 \mathrm{~g}$ supernatant fractions and inorganic buffers in the isolated, washed rumen enabled the one-way efflux of ${ }^{28} \mathrm{Mg}$ to be compared with net ${ }^{24} \mathrm{Mg}$ absorption. In all three sheep studied, the net rates of efflux of ${ }^{24} \mathrm{Mg}$ and ${ }^{28} \mathrm{Mg}$ from supernatant fractions and buffers were decreased when the $\mathrm{K}$ concentration was increased, and the decreases were similar for both isotopes (Table 4). This finding is in agreement with that recently noted by Beardsworth et al. (1987), but contrasts with that of Care et al. (1984) who concluded from work with a rumen pouch that an increased influx of ${ }^{24} \mathrm{Mg}$ from the blood to the rumen pouch was mainly responsible for the reduced net efflux of ${ }^{24} \mathrm{Mg}$. At the intrarumen $\mathrm{Mg}$ ion concentration of $2.4 \mathrm{mmol} / 1$ used by both groups, the electrochemical potential cannot support passive efflux of $\mathrm{Mg}$ ions from the rumen. Thus active transport must be responsible and one must conclude that the effect of the high rumen $\mathrm{K}$ concentration is probably by a direct inhibitory action on this active process. This conclusion has been confirmed by recent results obtained by Martens et al. (1987) from in vitro studies of $\mathrm{Mg}$ transport across rumen epithelium suspended in Ussing chambers. They showed that although the increase in potential difference across the epithelium, caused by high mucosal $\mathrm{K}$ concentration, does enhance the passive flux of $\mathrm{Mg}$ from the serosal to the mucosal side via a paracellular pathway, the magnitude of this response is far too small to account for the extent of the fall in net $\mathrm{Mg}$ flux from the mucosal to the serosal side.

One of the sheep used in the balance studies, and another used for the washed rumen experiments absorbed more $\mathrm{Mg}$ than the other sheep even when the $\mathrm{K}$ intake and concentrations in the rumen were increased. This has also been observed by others (P. M. Beardsworth and L. J. Beardsworth, personal communication). Field (1983) concluded that variation between ruminants in the efficiency of $\mathrm{Mg}$ absorption was greater than the inhibitory effects of $\mathrm{K}$. The present study also showed that the differences between individual sheep in their ability to absorb $\mathrm{Mg}$ from the $100000 \mathrm{~g}$ supernatant fraction or inorganic buffer were greater than the effects of increasing $\mathrm{K}$ concentration (Fig. 4). The differences in efficiency of $\mathrm{Mg}$ absorption between individual sheep may reflect differences in the absorptive area of rumen papillae.

The authors thank Mr. P. M. Beardsworth, Mrs L. J. Beardsworth, S. Davis and the staff of the Department of Animal Physiology and Nutrition for assistance with the care of the sheep and the chemical analyses. Mr G. A. Anderson, University of Melbourne, assisted with the statistical analysis. The study was financed in part by the Australian Meat Research Committee.

\section{REFERENCES}

Agricultural Research Council (1980). The Nutrient Requirements of Ruminant Livestock. Farnham Royal: Commonwealth Agricultural Bureaux.

Beardsworth, L. J., Beardsworth, P. M. \& Care, A. D. (1987). Journal of Physiology 386, 89P.

Bray, G. A. (1960). Analytical Biochemistry 1, 279--285.

Brown, R. C., Care, A. D. \& Pickard, D. W. (1978). Journal of Physiology 276, 62P-63P. 
Care, A. D., Brown, R. C., Farrar, A. R. \& Pickard, D. W. (1984). Quarterly Journal of Experimental Physiology 69, 577-587.

Dobson, A., Sellers, A. F. \& Gatewood, V. H. (1976). American Journal of Physiology 231, 1595 1600.

Field, A. C. (1983). In Role of Magnesium in Animal Nutrition, pp. 139-171 [J. P. Pontenot, G. E. Bunce, K. E. Webb Jr and V. G. Allen, editors]. Blacksburg, Virginia: Virginia Polytechnic Institute and State University.

Field, A. C. \& Munro, C. S. (1977). Journal of Agricultural Science, Cambridge 89, 365-371.

Field, A. C. \& Suttle, N. F. (1979). Journal of Comparative Pathology 89, 431- 439.

Grace, N. D. (1983). In Role of Magnesium in Animal Nutrition, pp. 107-120 [J. P. Fontenot, G. E. Bunce, K. E.

Webb Jr and V. G. Allen, editors). Blacksburg, Virginia: Virginia Polytechnic Institute and State University.

Grace, N. D., Ulyatt, M. J. \& MacRae, J. C. (1974). Journal of Agricultural Science, Cambridge 82, 321-330.

Martens, H. (1979). Berliner and Muenchener Tieraerziliche Wochenschrift 92, 152-155.

Martens, H. (1983). British Journal of Nutrition 49, 153-158.

Martens H., Gabel, G. \& Strozyk, P. (1987). Quarterly Journal of Experimental Physiology (In the press).

Martens, H., Harmeyer, J. \& Michael, H. (1978). Research in Veterinary Science 24, 161-168.

Martens, H. \& Rayssiguier, Y. (1980). In Digestive Physiology and Metabolism in Ruminants, pp 447-466. [Y.

Ruckebusch and P. Thivend, editors]. Lancaster: MTP Press Ltd.

Molloy, L. F. \& Richards, E. L. (1971). Journal of the Science of Food and Agriculture 22, 397-402.

Russell, J. B. \& van Soest, P. J. (1984). Journal of Applied and Environmental Microbiology 47, 155-159.

Scott, D. \& Dobson, A. D. (1965). Quarterly Journal of Experimental Physiology 50, 42--56.

Sjollema, B. (1931). Landbouwkindig Tijdschrift 43, 793-815.

SPSS (1986). SPSS User's Guide, 2nd ed. New York: McGraw-Hill Book Co.

Storry, J. E. (1961). Journal of Agricultural Science, Cambridge 57, 97-102.

Suttle, N. F. \& Field, A. C. (1967). British Journal of Nutrition 21, 819-831.

Suttle, N. F. \& Field, A. C. (1969). British Journal of Nutrition 21, 81-90.

Tomas, F. M. \& Potter, B. J. (1976). Australian Journal of Agricultural Research 27, 873-880. 